\title{
Comparison of short-term outcomes and invasiveness of microwave versus radiofrequency ablation for the treatment of hepatic tumors
}

\author{
Sumika Kagebayashi $^{1 \otimes}$, Seiya Kawahara ${ }^{2}$, Takeshi Kubo ${ }^{1}$, Hirokazu Sawamura ${ }^{2}$, Hisato Kobayashi ${ }^{3}$ \\ ${ }^{I}$ Department of Radiology, Tenri Hospital; ${ }^{2}$ Department of Radiology, Otsu Red Cross Hospital; ${ }^{3}$ Department of Radiology, \\ Kobe Asahi Hospital
}

Received 2020/12/11; accepted 2021/2/18; released online 2021/7/1

Purpose: Percutaneous ablation techniques, including microwave ablation (MWA) and radiofrequency ablation (RFA), are important minimally invasive treatment options for liver tumors. MWA is expected to provide a larger ablation zone than RFA in a shorter time. The aim of this study was to investigate the duration of ablation, the number of punctures, and technique efficacy of RFA versus MWA for hepatocellular carcinoma (HCC) and liver metastasis.

Methods: Between January 2014 and December 2018, 208 sessions with 274 tumors (263 HCCs and 11 liver metastases) treated by RFA and 32 sessions with 34 tumors ( 26 HCCs and 8 liver metastases) treated by MWA were enrolled in this retrospective study. We investigated age, sex, Child-Pugh classification, number, and size of tumors. Technical success (TS), local tumor progression (LTP), size and shape of the ablation zone, number of punctures, and duration of ablation were compared. Postoperative follow-up was performed with imaging studies performed between January 2014 and March 2019.

Results: The TS rate was $88.2 \%$ for MWA and $92.3 \%$ for RFA. The LTP rate after 3 months was $6.7 \%$ for MWA and $5.4 \%$ for RFA. The LTP rate after 6 months was $15.0 \%$ for MWA and $10.7 \%$ for RFA. There was no significant difference between MWA and RFA. The number of punctures per tumor was $1.42 \pm 0.56$ for MWA and $2.76 \pm 1.27$ for RFA. The duration of ablation per tumor was $10.40 \pm 4.26$ minutes for MWA and $23.20 \pm 10.54$ minutes for RFA. Compared with RFA, MWA caused spherical ablation in a shorter time with fewer punctures $(P<0.05)$.

Conclusion: MWA had similar short-term outcomes with fewer punctures and duration of ablation than RFA. MWA has potential as a less invasive treatment for liver tumors.

Key words: hepatocellular carcinoma, liver metastasis, microwave ablation, radiofrequency ablation

\section{INTRODUCTION}

Percutaneous ablation has recently become a valuable minimally invasive alternative to surgery for liver

$\bowtie$ Correspondence to: Sumika Kagebayashi, MD

Department of Radiology, Tenri Hospital

200 Mishima, Tenri, Nara 632-8552, Japan

e-mail: sumika.kage@gmail.com tumors. ${ }^{1}$ Image-guided thermal ablation therapy for HCC has been widely used as a therapeutic choice for unresectable and recurrent HCC patients because of its safety, minimal invasiveness, repeatability, and costeffectiveness. $^{2-5}$ The efficacy of percutaneous cautery has been reported not only for HCC, but also for liver 
metastases such as colon cancer. ${ }^{6}$

Although percutaneous ablation is considerably less invasive than laparotomy or laparoscopic surgery, ablation may take a certain length of time and require multiple punctures. The longer time and greater number of punctures required for ablation increases the burden on the patient, practitioner, and facility.

Radiofrequency ablation (RFA) is the most common thermal ablation modality worldwide, with a complete tumor necrosis rate of higher than $95 \%$ and 5-year disease-free survival (DFS) of $34 \%$ in patients with liver tumors. ${ }^{6-8}$

Microwave ablation (MWA) delivers high-frequency microwaves into the tissue, thereby causing the rapid rotation of molecules and thermal damage to tumors.' Although the indications for MWA and RFA are similar, MWA has some advantages over RFA in energy delivery such as higher treatment temperatures and less susceptibility to heat-sink effects.

We focused on this feature of MWA. RFA has a narrow range of ablation in one session; therefore, more treatment sessions are needed to obtain complete tumor necrosis with the appropriate margin. MWA can produce a large spherical cauterized field in a short time and may therefore require a shorter duration of ablation and smaller number of punctures than RFA.

Although the duration of ablation was reported to be shortened by MWA, ${ }^{10}$ there are few reports regarding the number of punctures compared with RFA. ${ }^{11}$ Moreover, there is no difference in treatment efficacy or safety between MWA and RFA. Therefore, we examined whether the use of MWA can reduce the number of punctures and duration of ablation without sacrificing the local control rate.

\section{MATERIALS AND METHODS}

All examinations and treatments performed at our institution were performed in accordance with the Helsinki Declaration and approved by the Clinical Research Board of Japanese Red Cross Otsu Hospital.
A retrospective review of the records in the procedure database from January 2014 to December 2018 was conducted to determine the study population. The inclusion criteria were: (1) a solitary tumor with the greatest diameter less than $4 \mathrm{~cm}$; three or fewer multiple tumors with the greatest diameter of $3 \mathrm{~cm}$ or less, (2) liver function of Child-Pugh class A or B, and (3) prothrombin time of greater than $50 \%$ and platelet count higher than $5.0 \times 10^{4} / \mu \mathrm{L}$. The diagnoses of the liver tumors were made clinically based on imaging and blood tests. The histological diagnosis of tumors was confirmed by US-guided fine needle biopsy if the clinical diagnosis was inconclusive. The review revealed 34 tumors (26 cases of $\mathrm{HCC}$, seven cases of metastatic colorectal cancer, and one case of metastatic pancreatic cancer) treated in 32 sessions by MWA and 274 tumors (263 cases of HCC, ten cases of metastatic colorectal cancer, and one case of metastatic lung cancer) treated in 208 sessions by RFA. No patient received chemotherapy within one year before the procedure. We recorded the age, sex, Child-Pugh classification, number, and size of the tumor.

The tumor size was measured using contrastenhanced computed tomography (CECT) or contrastenhanced magnetic resonance imaging (CEMRI) performed within two months before ablation. Ultrasound (LOGIQ E9, GE Healthcare, Tokyo, Japan) was used for guidance and monitoring of ablation procedures.

The Emprint Ablation System with Thermosphere Technology (Covidien Japan, Tokyo, Japan) was the MWA system used in this study. The size of the puncture needle was $13 \mathrm{G}$ and the length was $15 \mathrm{~cm}$. This new device is a $2,450-\mathrm{MHz}$ microwave ablation system, and consists of a 100-W generator with a highefficiency reusable cable and a coolant pump for probe cooling.

The Cool-tip RF ablation system (Covidien Japan) was used in this study. We measured the distance between the tumor and the body surface using US, and 


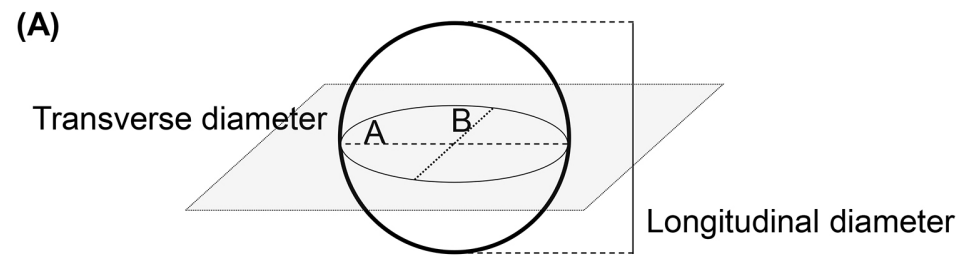

(B)

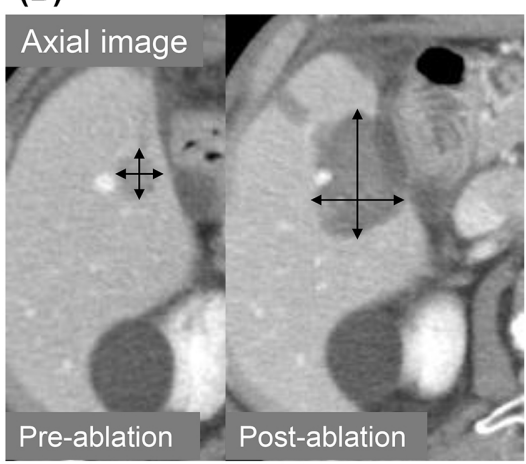

(C)

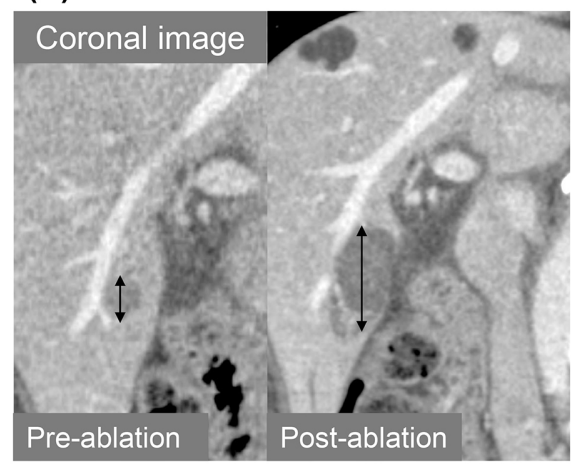

Figure 1. Evaluation of the shape of the tumor and ablation zone.

(A) Schematic presentation of the measurement protocol. Transverse diameter $A$ (represented by the dashed line) and $B$ (dotted line) were measured in the axial plane (shaded plane), and the longitudinal diameter (vertical solid line) was measured in the coronal plane.

(B) Transverse diameters $A$ and $B$ were measured on axial CECT images.

(C) The longitudinal diameter was measured on coronal CECT images. selected a suitable puncture needle from 10 or $15 \mathrm{~cm}$. The size of the puncture needle was $16 \mathrm{G}$. The system works by combining an RF generator with a maximum power output of $200 \mathrm{~W}$, an internally cooled needle electrode, and a dispersive pad to deliver therapeutic energy directly to the tumor.

The same pre-procedure preparations were made for MWA and RFA. The procedures were performed under local anesthesia with $1 \%$ lidocaine and conscioussedation analgesia was induced by intravenous administration of pentazocine. Under real-time ultrasound guidance, the antenna was percutaneously introduced into the tumors with the tip placed in the center of the nodule.

When MWA was used for cauterization, the tumor was first cauterized at $45 \mathrm{~W}$ for 1 minute, followed by cauterization at $75 \mathrm{~W}$. The cauterization time was determined according to the diameter of the tumor. The cauterization range was reviewed on the US image. If the cauterization range was judged to be suboptimal, MWA at $100 \mathrm{~W}$ was added.

When RFA was used, we started ablation at $20 \mathrm{~W}$ and increased the power by $5-10 \mathrm{~W}$ every minute up to $70-120 \mathrm{~W}$, and then ablation was performed with the appropriate energy until the end of the treatment. Cauterization of the tumor was stopped when the tumor and ablation margin were covered in the high echoic area on the US image. The needle track was cauterized while withdrawing the antenna to prevent possible tumor seeding.

The number of punctures and ablation time for a single tumor were recorded. To evaluate the shape of the ablation zone, we also compared the roundness index (RI). RI A, B, and transverse were defined as transverse diameter A divided by longitudinal diameter, transverse diameter $\mathrm{B}$ divided by longitudinal diameter, and transverse diameter $\mathrm{B}$ divided by transverse diameter A, respectively (Figure 1). Therefore, a value near 1.0 represents a more spherical ablation zone shape, whereas that distant from 1.0 indicates an oval configuration. $^{12}$

Based on the Standardization of Terminology and Reporting Criteria and W Shady et al., ${ }^{13,14}$ TS (technical success) was determined when the tumors were 
Table 1. Baseline clinical data of patients and characteristics of target lesions

\begin{tabular}{|c|c|c|c|}
\hline & $\operatorname{MWA}(n=32)$ & $\operatorname{RFA}(n=208)$ & $P$-value \\
\hline \multicolumn{4}{|l|}{ Target lesion } \\
\hline Single & 30 & 156 & $<0.05$ \\
\hline Multiple & 2 & 52 & \\
\hline \multicolumn{4}{|l|}{ Tumor type } \\
\hline $\mathrm{HCC}$ & 26 & 263 & $<0.05$ \\
\hline Metastasis & 8 & 11 & \\
\hline \multicolumn{4}{|l|}{ Age (range) } \\
\hline & $73 \pm 8.5^{*}(50-88)$ & $73 \pm 8.3^{*}(44-90)$ & 0.81 \\
\hline \multicolumn{4}{|l|}{ Sex } \\
\hline M & $21(65.6 \%)$ & $147(70.6 \%)$ & 0.69 \\
\hline $\mathrm{F}$ & $11(34.4 \%)$ & $61(29.4 \%)$ & \\
\hline \multicolumn{4}{|l|}{ Child-Pugh score } \\
\hline A & 29 & 168 & 0.10 \\
\hline B & 3 & 40 & \\
\hline \multicolumn{4}{|l|}{ Underlying disease } \\
\hline $\mathrm{HCV}$ & 12 & 165 & $<0.05$ \\
\hline HBV & 6 & 28 & \\
\hline $\mathrm{NASH}$ & 3 & 23 & \\
\hline Alcohol & 4 & 48 & \\
\hline Unknown & 3 & 9 & \\
\hline \multicolumn{4}{|l|}{ Tumor diameter (mm) } \\
\hline Transverse A (range) & $15.68 \pm 6.67^{*}(6-33)$ & $14.23 \pm 5.42^{*}(5-34)$ & 0.30 \\
\hline Transverse B (range) & $15.53 \pm 6.68^{*}(3-31)$ & $13.93 \pm 4.90^{*}(5-33)$ & 0.25 \\
\hline Longitudinal (range) & $15.44 \pm 6.0^{*}(5-28)$ & $13.82 \pm 5.13^{*}(4-39)$ & 0.14 \\
\hline
\end{tabular}

MWA, microwave ablation; RFA, radiofrequency ablation; HCC, hepatocellular carcinoma; HCV, hepatitis $\mathrm{C}$ virus; $\mathrm{HBV}$, hepatitis B virus; and NASH, non-alcoholic steatohepatitis.

${ }^{*}$ Data are presented as mean \pm SD.

Table 2. The outcomes regarding puncture, ablation time, and ablation zone

\begin{tabular}{lccc}
\hline & MWA & RFA & $P$-value \\
\hline Number of punctures $(\mathrm{n})$ & $1.42 \pm 0.56$ & $2.76 \pm 1.27$ & $<0.05$ \\
Duration of ablation per tumor (minute) & $10.40 \pm 4.26$ & $23.20 \pm 10.54$ & $<0.05$ \\
Ablation zone size (mm) & & & \\
$\quad$ Laterally (range) & $36.0 \pm 9.3(20-57)$ & $34.2 \pm 7.6(19-69)$ & 0.15 \\
Anteroposteriorly (range) & $34.0 \pm 8.4(21-54)$ & $32.6 \pm 8.1(14-56)$ & 0.30 \\
Craniocaudally (range) & $38.0 \pm 9.1(17-59)$ & $33.0 \pm 8.2(17-60)$ & $<0.05$ \\
RI & & & \\
RI A & $0.97 \pm 0.21$ & $1.07 \pm 0.25$ & $<0.05$ \\
RI B & $0.92 \pm 0.20$ & $1.02 \pm 0.25$ & $<0.05$ \\
RI transverse & $0.98 \pm 0.22$ & $0.97 \pm 0.22$ & 0.75 \\
\hline
\end{tabular}

MWA, microwave ablation; RFA, radiofrequency ablation; RI, roundness index.

Data are presented as mean \pm SD. 
included in the ablation zone with a sufficient safety margin (at least $>5 \mathrm{~mm}$ ).

Local tumor progression (LTP) of the previously treated tumor with TS was defined as the appearance of tumor tissue at the edge of the ablation zone detected by contrast-enhanced follow-up study. The technical efficacy was defined as the absence of LTP. Postablation follow-up examination with imaging studies was performed between January 2014 and March 2019. Using CECT or CEMRI, TS was assessed two days after the procedure, and technique efficacy was assessed at 3 and 6 months after the procedure. There were no cases of additional treatment, such as transcatheter arterial chemoembolization or systemic chemotherapy, between the procedure and follow-up imaging. Patients whose tumors did not achieve TS due to residual tumor were excluded from the 3-month post-treatment evaluation.

Major complications were defined as an event leading to substantial morbidity and disability (e.g., resulting in the unexpected loss of an organ) that increases the level of care, results in hospital admission, or substantially lengthens the hospital stay. ${ }^{13}$

\section{Statistical analysis}

The clinical data of the patients undergoing RFA and MWA, duration of ablation, and number of punctures were compared using the Mann-Whitney U test, whereas the rates of TS and LTP after 3 and 6 months were compared by Pearson's Chi-square test. $P<0.05$ was considered to indicate a significant difference.

Data analysis was performed with EZR (Saitama Medical Center, Jichi Medical University, Saitama, Japan) ${ }^{15}$ which is a graphical user interface for $\mathrm{R}$ (The R Foundation for Statistical Computing, Vienna, Austria). ${ }^{16}$ Values for quantitative variables were expressed as the mean \pm standard deviation (SD).

\section{RESULTS}

All patients completed MWA or RFA treatment in a single session. The total number of treated lesions was 34 for MWA and 274 for RFA. TS was achieved in all tumors. The cases evaluable at 3 and 6 months after treatment were 30 and 20 tumors treated by MWA, 242 and 215 tumors treated by RFA, respectively.

The patient profile and characteristics of target tumors are summarized in Table 1. Multiple tumors were present in 2/32 sessions in MWA (6\%) and 52/208

Table 3. The outcomes regarding complete ablation, local tumor progression, and complications

\begin{tabular}{lccc}
\hline & MWA & RFA & $P$-value \\
\hline Technical success & & & \\
Complete ablation & $88.2 \%(30 / 34)$ & $92.3 \%(253 / 274)$ & 0.38 \\
Lack of safety margin & $2.9 \%(1 / 34)$ & $3.3 \%(9 / 274)$ & \\
Residual tumor & $8.8 \%(3 / 34)$ & $4.4 \%(12 / 274)$ & \\
Local tumor progression & & & 0.68 \\
3 months & $6.7 \%(2 / 30)$ & $5.4 \%(13 / 242)$ & 0.47 \\
6 months & $15.0 \%(3 / 20)$ & $10.7 \%(23 / 215)$ & \\
Complication & $11.8 \%(4 / 34)$ & $14.2 \%(39 / 274)$ & \\
Fever & $2.9 \%(1 / 34)$ & $0.3 \%(1 / 274)$ & \\
Hemorrhage & 0 & $0.3 \%(1 / 274)$ & \\
Hepatic necrosis & 0 & $1.1 \%(3 / 274)$ & \\
Biloma & & & \\
\hline
\end{tabular}

MWA, microwave ablation; RFA, radiofrequency ablation. 
sessions in RFA (25.0\%). There were more metastatic tumors in the MWA group and there was a difference in the underlying disease between the two groups. There were no significant differences in other patient characteristics.

The number of punctures, duration of ablation, size, and RI of ablation zones are described in detail in Table 2. The ablation zone was larger craniocaudally in MWA than in RFA, and consequently, there was a difference in RI A and B between the two groups. However, we concluded that both techniques produced acceptable spherical ablation zones. Significantly fewer punctures and a shorter duration of ablation were noted in the MWA group than in the RFA group $(P<0.05)$.

The treatment outcomes are described in detail in Table 3. The TS rate was $88.2 \%(30 / 34)$ in the tumors treated by MWA and 92.3\% (253/274) in those treated by RFA, with no significant difference. LTP after 3 months was observed in 2 tumors $(6.7 \%)$ treated by MWA and in 13 tumors (5.4\%) treated by RFA. LTP after 6 months was observed in 3 tumors (15.0\%) treated by MWA and in 23 tumors $(10.7 \%)$ treated by

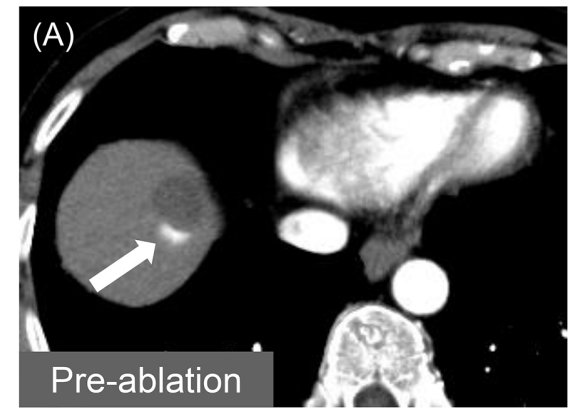

Figure 2.

(A) Local tumor recurrence beneath the diaphragm after RFA.

(B) The target remains 2 days after MWA. (C) US image during the MWA procedure. It was difficult to puncture with the MWA antenna because it was a small lesion far from the body surface.
RFA. There was no significant difference between MWA and RFA. Recurrent tumors included 2 cases of HCC and 1 case of liver metastasis in the MWA group, and 20 cases of HCC and 3 cases of liver metastasis in the RFA group.

Four (11.8\%) patients after MWA and 32 (14.2\%) after RFA developed fever and received antibiotics. There was one case of hemorrhage requiring intravascular embolization in each group. During the observation period, we detected biloma around the treatment area in three patient who underwent RFA. There was one case of hepatic necrosis after RFA treatment. There were no significant differences in the incidence rates of complications between the MWA and RFA groups (MWA/RFA: 14.7/16.1\%). No skin burns, tumor seeding, or treatment-related death was observed in this study.

\section{DISCUSSION}

This study confirmed that MWA produced short-term outcomes comparable to RFA. It also demonstrated that MWA ablation needs fewer punctures and a shorter
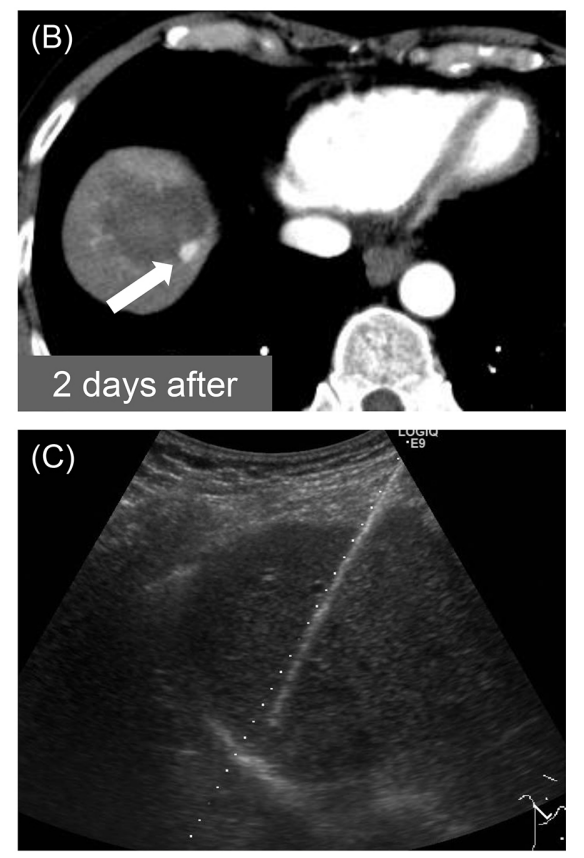
ablation length than RFA, with a comparable rate of complications.

Local ablation of hepatic tumors is considered the first-line treatment option for early HCC and metastatic tumors that are unsuitable for surgical therapies. Since the 1990s, several RFA systems have been developed in the United States and Europe. RFA was demonstrated to be safe, effective, and have repeatable coagulative performance, and was rapidly accepted as the method of choice for tumor ablation. Over the last ten years, a new generation of MWA was developed. The new generation of MWA was designed to create a large predictable spherical ablation zone unaffected by changes in the tissue environment. ${ }^{17}$

MWA has the distinct advantage of energy penetration through high-impedance tissues, making it possible to ablate lesions, such as in regions nearby vessels, which is not possible using RFA. Due to these properties, new-generation MWA devices are expected to result in faster ablation and larger ablation volumes than RFA. ${ }^{18}$

This study suggested that fewer punctures and a shorter ablation time are possible if MWA is used instead of RFA. Although there are reports that the duration of ablation is shortened by MWA, ${ }^{10}$ there are few regarding the number of punctures compared with RFA. ${ }^{11}$ A shorter ablation time and fewer punctures will translate into an overall shorter procedure time. As such, it will benefit both the patients and care providers. In addition, there was no difference in the rate of puncture complications between MWA and RFA in this study. No difference in the complication rate was observed despite the thicker puncture needle in MWA, which may be related to the smaller number of punctures. However, due to the small number of patients in this study, future studies are required to examine the relationship between the number of punctures and complications.

There are many reports that there is no significant difference in outcomes between MWA and RFA. Local recurrence and complication rates of MWA for HCC and liver metastases were reported to be $2.9-17.8 \%$ and $6.0-8.6 \%$, and $2.6-61.5 \%$ and $27-57.1 \%$, respectively. In contrast, those of RFA for $\mathrm{HCC}$ and liver metastases were $0-46.6 \%$ and $10-35.7 \%$, and $0-45.4 \%$ and $3.2-$ $24 \%$, respectively. ${ }^{6,19}$ In a study that included both HCC and liver metastases, DFS was slightly higher by MWA than by RFA at 1 year ( $83 \%$ vs. $81 \%), 3$ years $(57 \%$ vs. $51 \%$ ), and 5 years (39\% vs. $34 \%){ }^{6}$ As in previous reports, there was no significant difference between them in the complete ablation rate or local recurrence rate after 3 or 6 months in this study.

The rate of residual tumors is often high in patients treated by MWA. In this series, three cases of residual tumor were observed after MWA. Among these three cases, two were of one tumor treated twice. It was local tumor recurrence of HCC located beneath the diaphragm, which was previously treated by RFA one year before. Although the tumor was visible on US, puncture was technically challenging because it was distant from the body surface and the tumor moved upon breathing (Figure 2). Therefore, complete ablation was not attained, leaving residual tumor on the superior side of the ablation field. This particular case may have led to the higher rate of residual tumor with MWA.

MWA and RFA are essential in the local treatment of liver tumors. Regarding the burden of the procedure on patients, MWA with fewer punctures and a shorter ablation duration is advantageous. Moreover, MWA may be more appropriate, especially for larger lesions, as there are reports that MWA has a lower local recurrence rate than RFA for large $(>3 \mathrm{~cm})$ lesions. $^{20}$ However, it is also important to note that the MWA puncture needle and RFA puncture needle have different structures, and the MWA puncture needle has lower visibility on US. Therefore, deeper lesions, such as subdiaphragmatic tumors mentioned above, are likely to be more safely treated by RFA than by MWA, as echo attenuation impairs visibility of the lesions distant from the body surface. The treatment results 
will improve by using two procedures depending on the lesion size and location if both are available.

The current study examining the invasiveness of the new generation of MWA devices regarding the number of punctures and duration of ablation may form the basis of a prospective study on this topic with few previous reports.

There are several limitations in our study. Although there were no significant differences in the patient profiles between the two groups, there may have been potential bias because this was a retrospective and non-randomized study. Second, the long-term results between RFA and MWA were unable to be examined because the follow-up period was six months. Third, the sample size of patients treated by MWA was small. Additional studies with a longer follow-up and more patients are required for further efficacy evaluation and survival analysis. Fourth, in this study, tumor size was evaluated using imaging studies within two months prior to treatment. Therefore, the reported sizes do not precisely reflect those at the time of treatment. However, the size of the tumor was directly confirmed by US during ablation. No major inconsistency in size was observed between the preoperative examination and the time of treatment.

In conclusion, MWA was demonstrated to be as safe and effective as RFA in the treatment of HCC or liver metastases. MWA required fewer punctures and a shorter cauterization time than RFA. This suggests that MWA is a less invasive treatment option more favorably accepted by patients.

\section{C.O.I. DISCLOSURE}

The authors have no conflicts of interest directly relevant to the content of this article.

\section{REFERENCES}

1. Verslype C, Rosmorduc O, Rougier P, et al. Hepatocellular carcinoma: ESMO-ESDO Clinical Practice Guidelines for diagnosis, treatment and follow-up. Ann Oncol 2012;23 Suppl 7:vii41-48.

2. Llovet JM, Burroughs A, Bruix J. Hepatocellular carcinoma. Lancet 2003;362:1907-1917.

3. Llovet JM, Bruix J. Novel advancements in the management of hepatocellular carcinoma in 2008. J Hepatol 2008;48 Suppl 1:S20-37.

4. Lau WY, Leung TW, Yu SC, et al. Percutaneous local ablative therapy for hepatocellular carcinoma: A review and look into the future. Ann Surg 2003;237:171-179.

5. Poon RT, Fan ST, Tsang FH, et al. Locoregional therapies for hepatocellular carcinoma: A critical review from the surgeon's perspective. Ann Surg 2002;235:466-486.

6. Glassberg MB, Ghosh S, Clymer JW, et al. Microwave ablation compared with radiofrequency ablation for treatment of hepatocellular carcinoma and liver metastases: A systematic review and meta-analysis. Onco Targets Ther 2019;12:6407-6438.

7. Ikeda M, Okada S, Ueno H, et al. Radiofrequency ablation and percutaneous ethanol injection in patients with small hepatocellular carcinoma: A comparative study. Jpn J Clin Oncol 2001;31:322-326.

8. Dodd GD, 3rd, Soulen MC, Kane RA, et al. Minimally invasive treatment of malignant hepatic tumors: At the threshold of a major breakthrough. Radiographics 2000;20:9-27.

9. Alonzo M, Bos A, Bennett S, et al. The Emprint ${ }^{\mathrm{TM}}$ ablation system with Thermosphere ${ }^{\mathrm{TM}}$ technology: One of the newer nextgeneration microwave ablation technologies. Semin Intervent Radiol 2015;32:335-338.

10. Poulou LS, Botsa E, Thanou I, et al. Percutaneous microwave ablation vs radiofrequency ablation in the treatment of hepatocellular carcinoma. World J Hepatol 2015;7:1054-1063.

11. Suwa K, Seki T, Tsuda R, et al. Short term treatment results of local ablation with water-cooled microwave antenna for liver cancer: Comparison with radiofrequency ablation. Mol Clin Oncol 2020;12:230-236.

12. Park MJ, Kim YS, Rhim H, et al. A comparison of US-guided percutaneous radiofrequency ablation of medium-sized hepatocellular carcinoma with a cluster electrode or a single electrode with a multiple overlapping ablation technique. J Vasc 
Interv Radiol 2011;22:771-779.

13. Ahmed M, Solbiati L, Brace CL, et al. Image-guided tumor ablation: Standardization of terminology and reporting criteria--a 10-year update. Radiology 2014;273:241-260.

14. Shady W, Petre EN, Do KG, et al. Percutaneous microwave versus radiofrequency ablation of colorectal liver metastases: Ablation with clear margins (A0) provides the best local tumor control. J Vasc Interv Radiol 2018;29:268-275.

15. Kanda Y. Investigation of the freely available easy-to-use software 'EZR' for medical statistics. Bone Marrow Transplant 2013;48:452-458.

16. R Core Team (2013). R: A language and environment for statistical computing. R Foundation for Statistical Computing. Viena, Austria. Available at: http://www.R-project.org/.

17. Imajo K, Tomeno W, Kanezaki M, et al. New microwave ablation system for unresectable liver tumors that forms large, spherical ablation zones. J Gastroenterol Hepatol 2018;33:2007-2014.

18. Yu NC, Raman SS, Kim YJ, et al. Microwave liver ablation: Influence of hepatic vein size on heat-sink effect in a porcine model. J Vasc Interv Radiol 2008;19:1087-1092.

19. Izzo F, Granata V, Grassi R, et al. Radiofrequency ablation and microwave ablation in liver tumors: An update. Oncologist 2019;24:e990-e1005.

20. Facciorusso A, Di Maso M, Muscatiello N. Microwave ablation versus radiofrequency ablation for the treatment of hepatocellular carcinoma: A systematic review and meta-analysis. Int J Hyperthermia 2016;32:339-344. 


\section{肝腫瘍治療におけるマイクロ波アブレーション（microwave ablation）とラジオ波焼灼術 (radiofrequency ablation) の比較検討}

影林 純佳 $^{1}$, 川原 清哉 ${ }^{2}$, 久保 武 $^{1}$, 沢村 博一 ${ }^{2}$, 小林 久人 ${ }^{3}$

${ }^{1}$ 天理よろづ相談所病院 放射線科

2 大津赤十字病院 放射線科

3 神戸朝日病院 放射線科

【目的】肝臟腫瘍の局所療法としてラジオ波焼灼術（RFA）は広く普及し施行されている．新世代のマイクロ波焼 灼術（MWA）はRFA と比べ短い時間で球状の広い焼灼野を得ることができる. この特徵は穿刺回数の減少や手技 時間の短縮につながり，より低侵襲の治療が可能になると期待される．そこで我々は，肝細胞癌（HCC）と転移 性肝腫瘍の治療における有効性と焼灼時間，穿刺回数について MWA RFA と比較検討した.

【方法】2014 年 1 月から 2018 年 12 月の間に行われた MWA 34 例（HCC 26 例，転移性肝腫瘍 8 例），および RFA 274 例（HCC 263 例、転移性肝腫瘍 11 例）を対象として焼灼時間および穿刺回数，直後奏効率， 3 か月後と 6 か月後の局所再発率，合併症について比較検討を行った.

【結果】直後奏効率は MWA 88.2\%，RFA 92.3\%で両者に差は見られなかった. 3 力月後および 6 か月後の局所再 発率はそれぞれ MWA で $6.7 \%$ と 15.0\%，RFA で5.4\%と 10.7\% で，いずれも MWA とRFA の間に有意差は見ら れなかった. 焼灼時間および穿刺回数は MWA で $10.40 \pm 4.26$ 分, $1.42 \pm 0.56$ 回，RFA では $23.20 \pm 10.54$ 分， 2.76 \pm 1.27 回と，有意差をもって MWA 群で少ない值を示した. 合併症の発生頻度は両者で有意な差は見られなかった. 【結語】MWA は少ない穿刺回数と短い焼灼時間でRFA と同等の効果を得ることができた．長期予後については検 討が待たれるが，MWA はより侵襲度の低い治療として，肝腫瘍治療の重要な位置を占める可能性がある.

キーワード : 肝細胞癌，転移性肝腫瘍，マイクロ波アブレーション，ラジオ波焼灼術 